\title{
Analisis Faktor Individu, Pekerjaan dan Perilaku K3 pada Kejadian Penyakit Dekompresi pada Nelayan Penyelam Tradisional di Ambon
}

\author{
Yowan Embuai \\ Magister Promosi Kesehatan K3 (Keselamatan dan Kesehatan Kerja), Fakultas Kesehatan Masyarakat, \\ Universitas Diponegoro; oanaembuai@gmail.com \\ Hanifa Maher Denny \\ Fakultas Kesehatan Masyarakat, Universitas Diponegoro \\ Yuliani Setyaningsih \\ Fakultas Kesehatan Masyarakat, Universitas Diponegoro
}

\begin{abstract}
This study aims to analyze individual, occupational, and occupational health and safety behavior factors for decompression events in traditional diver fishermen in Ambon. Decompression is a disease in the form of an abnormality due to the release of gas bubbles in the blood due to decreased air pressure under the sea. This research was conducted on traditional diver fishermen using the case control research design and using nonprobability sampling techniques. Data collection tools in the form of questionnaires, interviews with respondents, and direct observation, using a measuring instrument. Data analysis used in the form of univariate, bivariate and multivariate with the use of SPSS statistical program. The results were obtained: there was a significant relationship between the length of work with decompression disease, there was a significant relationship between depth of diving and decompression disease, there was a significant relationship between duration of diving and decompression, there was a significant relationship between the frequency of diving and decompression, there is no significant relationship between safety and health behavior of water consumption and decompression disease, there is a significant relationship between occupational health and safety behavior using personal protective equipment with decompression sickness, the existence of a relationship which is not significant between occupational safety and health behavior of cigarette consumption and decompression disease, there is an insignificant relationship between occupational safety and health behavior of alcohol consumption and ser ta see the risk of each variable.
\end{abstract}

Keywords: decompression; occupational safety and health behavior; traditional fishermen; diving risk factors

\begin{abstract}
ABSTRAK
Penelitian ini bertujuan untuk menganalisis faktor individu, pekerjaan, dan perilaku K3 terhadap kejadian dekompresi pada nelayan penyelam tradisional di Ambon. Penyakit dekompresi merupakan penyakit berupa kelainan akibat pelepasan gelembung gas dalam darah akibat dari tekanan udara dibawah laut menurun. Penelitian ini dilakukan pada nelayan penyelam tradisional dengan mnggunakan desain penelitian case control dan menggunakan teknik nonprobability sampling. Alat pengumpulan data berupa kuisioner, wawancara dengan responden, dan observasi secara langsung, dengan menggunakan alat ukur. Analisis data yang digunakan berupa univariat, bivariat dan multivariat dengan penggunaan program statistik SPSS. Hasil penelitian diperoleh : adanya hubungan yang tidak signifikan dengan antara masa kerja dengan penyakit dekompresi adanya hubungan yang signifikan antara kedalaman menyelam dengan penyakit dekompresi, adanya hubungan yang signifikan antara lama menyelam dengan penyakit dekompresi, adanya hubungan yang signifikan antara frekuensi menyelam dengan penyakit dekompresi, adanya hubungan yang tidak signifikan antara kecepatan naik ke permukaan dengan penyakit dekompresi, adanya hubungan yang tidak signifikan antara perilaku K3 konsumsi air putih dengan penyakit dekompresi, adanya hubungan yang signifikan antara perilaku K3 penggunan APD dengan penyakit dekompresi, adanya hubungan yang tidak signifikan antara perilaku K3 konsumsi rokok dengan penyakit dekompresi, adanya hubungan yang tidak signifikan antara perilaku K3 kerja konsumsi alkohol dengan penyakit dekompresi serta melihat besar risiko setiap variabel.
\end{abstract}

Kata Kunci: dekompresi; perilaku keselamatan dan kesehatan kerja; nelayan tradisional; faktor risiko menyelam

\section{PENDAHULUAN}

\section{Latar Belakang}

Menurut undang-undang tentang Nelayan No. 45 tahun 2009, nelayan merupakan orang yang mata pencahariannya adalah melakukan penangkapan ikan, dan menurut Peraturan Menteri perhubungan No. 71 tahun 2013 penyelam adalah orang yang mempunyai keahlian untuk melakukan kegiatan di dalam air dengan tekanan lingkungan lebih besar dari 1 (satu) Atmosfir Absolut (ATA) yang telah mengikuti pendidikan dan pelatihan serta memiliki sertifikat kompetensi. ${ }^{(1)}$ 
Penyelam tradisional merupakan suatu profesi bagi para nelayan yang mempunyai mata pencaharian sebagian besar di laut. Namun untuk penyelam tradisional yang berada pada beberapa daerah pesisir, menggunakan alat bantu penyelaman seperti kompresor sebagai alat bantu penyelaman, maupun tidak menggunakan peralatan apapun saat melakukan penyelaman. Sehingga Salah satu dampak yang paling serius yang ditimbulkan akibat aktivitas menyelam adalah penyakit dekompresi maupun penurunan Kapasitas Vital Paru. Dalam melakukan penyelaman pada harus menggunakan peralatan selam yang sudah memenuhi standar. Selain melakukan penyelaman dengan alat yang sudah terstandar, ada juga penyelaman yang dilakukan tanpa menggunakan peralatan apapun, inilah yang disebut dengan penyelam tradisional. ${ }^{(2)}$

Penyakit Dekompresi merupakan suatu kondisi dimana gejala yang ditimbulkan dapat mengakibatkan penurunan tekanan udara di bawah air laut pada saat aktivitas menyelam dilakukan. Penyakit dekompresi terjadi akibat peningkatan tekanan yang cukup besar dibawah air laut. Penyakit ini disebabkan oleh pelepasan gelembung-gelembung gas dalam darah atau jaringan tubuh akibat penurunan tekanan dibawah air laut yang dapat berlangsung cepat. ${ }^{(3)(4)}$

Dalam melakukan sebuah pekerjaan harus memperhatikan dan menerapkan yang namanya perilaku keselamatan dan juga kesehatan kerja yang dimana harus diterapkan dalam lingkungan pekerjaan, yang bertujuan untuk mengontrol sumber daya manusia maupun suatu lembaga untuk dapat mengawasi dan meminimalisirkan bahaya yang akan datang untuk mengancam para pekerja. Sehingga ketika diterapkannya perilaku yang selamat dengan menjaga keselamatan dan juga kesehatan para pekerja, dengan demikian dapat mengurangi dampak dari kecelakaan kerja dan penyakit akibat kerja yang ditimbulkan, sehingga produtifitas kerja akan selalu meningkat secara efisien maupun bahaya maupun risiko dari penyakit yang akan didapati untuk kemudian harinya.

Angka kasus penyakit dekompresi di Amerika Serikat untuk tipe II (berat) sebanyak 2,28 kasus per 10.000 penyelam, tipe I (ringan) tidak dietahui datanya, dikarenakan mereka tidak mencari pengobatan. Di Kepulauan Hawai dan pulau-pulau di seluruh Asia Pasifik. Insiden peyakit dekompresi terkait dengan menyelam berkisar dari 1 hingga 35 kejadian per 1000 penyelaman. Kemudian untuk Hasil survey yang dilakukan pada 145 nelayan di Kabupaten Kepulauan Seribu, Jakarta Utara, menunjukan 81 responden menderita penyakit akibat penyelaman antara lain meliputi barotrauma telinga, dekompresi, dan penyakit akibat lingkungan dalam air. Hasil dari Kepulauan Seribu, dan DKI Jakarta 69,1\% kasus penyelam menderita kelainan dekompresi yang di sebabkan tidak tercukupinya gas nitrogen akibat penurunan tekanan dibawah laut. ${ }^{(5)(6)}$

Survey juga dilakukan oleh Kementerian Kesehatan, dengan 251 responden penyelam di 9 provinsi dengan keluhan yang sering dirasakan antara lain 21,2\% dengankeluhan pusing/sakit kepala, 12,6\% merasakan kelelahan, 12,5\% menurunnya frekuensi pendengaran, 10,8\% merasakan nyeri pada persendian, 10,2\% perdarahan pada hidung, 9,7\% sakit pada bagian dada/sesak nafas, $6,4 \%$ penurunan penglihatan, $6,0 \%$ bercak pada kulit, 5,6\% gigitan binatang, 3,2\% lumpuh dan 1,7\% mengalami hilang kesadaran. Sedangkan daerah Sulawesi Tenggara angka penyakit tahun 2012, untuk kasus penyakit dekompresi dengan distribusi kasus sebanyak 792 kasus dimana 54 kasus diantaranya adalah penderita penyakit dekompresi sebesar 6,81\%. ${ }^{(7)}$

Berdasarkan studi pendahuluan yang dilakukan di Rumah Sakit Lantamal Angkatan Laut Halong Ambon terdapat adanya kasus penyakit dekompresi dengan keluhan antara lain : 15,2\% merasa lemas, 20,9\% pusing/sakit kepala, 12,3\% merasakan keram pada anggota tubuh, dan 2,8\% nelayan yang pingsan dan hilang kesadaran selama beberapa menit.

Masalah kesehatan pada penyelam tradisional merupakan masalah yang perlu menjadi perhatian penting. Banyak masalah kesehatan yang dialami oleh penyelam salah satunya yaitu penyakit dekompresi. Beberapa faktor risiko pada penyelaman bisa berdampak pada kejadian penyakit dekompresi. Bahkan pada daerah-daerah tertentu masih banyak juga kasus dekompresi yang belum terdeteksi dan diketahui, karena adanya keterbatasan dan kekurangan dana yang juga menjadi masalah bagi nelayan disana untuk melakukan pengobatan lebih intensif. Penerapan perilaku keselamatan dan kesehatan kerja (K3) di kalangan nelayan perlu diterapkan dan ditingkatkan lagi untuk menghindari kecelakan kerja maupun penyakit akibat kerja yang ditimbulkan. Namun pada umumnya nelayan yang bertempat tinggal didaerah pesisir ambon belum memahami betul pentingnya penerapan perilaku K3 yang tepat dalam melakukan suatu pekerjaan. Dikarenakan tidak adanya control maupun pengawasan yang tepat untuk dilakukan serta kurangnya pengetahuan dari setiap individu terkait dengan kecelakaan kerja yang dapat mengancam, terkhususnya penyakit dan kecelakaan kerja yang ditimbulkan dari pekerjaan yang dilakukan.

Dari uraian tersebut maka peneliti akan melakukan penelitian untuk melihat apa saja hubungan faktor risiko individu, pekerjaan, dan perilaku K3 pada kejadian Penyakit Dekompresi pada nelayan penyelam tradisional di Ambon.

\section{Tujuan Penelitian}

Tujuan penelitian adalah untuk menganalisis faktor risiko individu yang meliputi masa kerja, faktor pekerjaan yang meliputi kedalaman menyelam, lama menyelam, frekuensi menyelam, dan kecepatan naik 
kepermukaan, dan penerapan perilaku K3 yag meliputi konsumsi air putih penggunaan APD, merokok, dan konsumsi alkohol, pada kejadian penyakit dekompresi pada nelayan penyelam tradisional di Ambon.

\section{METODE}

Penelitian ini merupakan penelitian dengan menggunakan metode penelitian case-control. Untuk penelitian case control menggunakan rasio 1:1 yaitu dimana jumlah objek penelitian pada kelompok kasus bejumlah 30 yang sama dengan jumlah subjek penelitian pada kelompok control yaitu 30. Teknik sampling yang digunakan menggunakan nonprobability sampling dengan teknik pengambilan sampel yang tidak memberikan peluang/kesempatan yang sama bagi setiap unsur atau anggota populasi yang dipilih menjadi sampel. Teknik ini menggunakan teknik purposive sampling dimana penentuan sampel berdasarkan dengan pertimbangan tertentu. Penelitian ini dilaksanakan di Ambon, dilakukan selama 2 bulan penelitian dan sasarannya pada nelayan penyelam tradisional yang bertempat tinggal didaerah pesisir. Instrument penelitian yang digunakan dalam melakukan penelitian ini adalah menggunakan kuisioner penelitian/pedomana wawancara mendalam. ${ }^{(8)}$

\section{HASIL}

\section{Analisis Deskriptif}

Tabel 1. Distribusi karakteristik responden

\begin{tabular}{|c|c|c|c|c|c|c|}
\hline \multirow{2}{*}{ Karakteristik } & \multicolumn{2}{|c|}{ Kasus } & \multicolumn{2}{|c|}{ Kontrol } & \multicolumn{2}{|c|}{ Total } \\
\hline & Frekuensi & Persen & Frekuensi & Persen & Frekuensi & Persen \\
\hline \multicolumn{7}{|l|}{ Umur } \\
\hline - $20-29$ tahun & 3 & $10.00 \%$ & 2 & $6.67 \%$ & 5 & $8.33 \%$ \\
\hline - $30-39$ tahun & 17 & $56.67 \%$ & 18 & $60.00 \%$ & 35 & $58.33 \%$ \\
\hline - $40-49$ tahun & 8 & $26.67 \%$ & 7 & $23.33 \%$ & 15 & $25.00 \%$ \\
\hline$\bullet>49$ tahun & 2 & $6.67 \%$ & 3 & $10.00 \%$ & 5 & $8.33 \%$ \\
\hline \multicolumn{7}{|l|}{ Tingkat pendidikan } \\
\hline - Tidak sekolah & 7 & $23.33 \%$ & 3 & $10.00 \%$ & 10 & $16.67 \%$ \\
\hline - SD & 12 & $40.00 \%$ & 16 & $53.33 \%$ & 28 & $46.67 \%$ \\
\hline - SMP & 8 & $26.67 \%$ & 4 & $13.33 \%$ & 12 & $20.00 \%$ \\
\hline - SMA & 3 & $10.00 \%$ & 7 & $23.33 \%$ & 10 & $16.67 \%$ \\
\hline Total responden & 30 & $50.00 \%$ & 30 & $50.00 \%$ & 60 & $100.00 \%$ \\
\hline
\end{tabular}

Karakteristik umur terbanyak terdapat pada kelompok kasus adalah pada usia 30-39 (56,67\%) dan pada kelompok kontrol adalah pada usia yang sama (60,00\%). Sedangkan karakteristik berdasarkan tingkat pendidikan terbanyak pada kelompok kasus adalah tingkat pendidikan SD dengan presentase $40,00 \%$ dan pada kelempok kasus pada tingkat pendidikan yang sama dengan persentase 53,33\%.

Tabel 2. Distribusi masa kerja, kedalaman menyelam, lama menyelam, frekeunsi menyelam, kecepatan naik kepermukaan, dan perilaku K3 (konsumsi air putih, penggunaan APD, merokok, dan konsumsi alkohol)

\begin{tabular}{|c|c|c|c|c|c|}
\hline No & Variabel & Kasus (n) & $\%$ & Kontrol (n) & $\%$ \\
\hline \multirow[t]{3}{*}{1} & Masa kerja & & & & \\
\hline & $>10$ tahun & 22 & $95,70 \%$ & 24 & $96,00 \%$ \\
\hline & $<10$ tahun & 1 & $4,30 \%$ & 1 & $4.00 \%$ \\
\hline \multirow[t]{3}{*}{2} & Kedalaman menyelam & & & & \\
\hline & 10 meter & 6 & $26,10 \%$ & 8 & $32,00 \%$ \\
\hline & $>10$ meter & 17 & $73,90 \%$ & 17 & $68,00 \%$ \\
\hline \multirow[t]{3}{*}{3} & Lama menyelam & & & & \\
\hline & 1 jam & 8 & $34,80 \%$ & 4 & $16,00 \%$ \\
\hline & $>1$ jam & 15 & $65,20 \%$ & 21 & $84,00 \%$ \\
\hline \multirow[t]{3}{*}{4} & Frekuensi menyelam & & & & \\
\hline & $1 \mathrm{kali} / \mathrm{hari}$ & 3 & $13,00 \%$ & 2 & $8,00 \%$ \\
\hline & $>1 \mathrm{kali} / \mathrm{hari}$ & 20 & $87,00 \%$ & 23 & $92,00 \%$ \\
\hline \multirow[t]{3}{*}{5} & Kecepatan naik kepermukaan & & & & \\
\hline & Tidak cepat & 18 & $78,30 \%$ & 18 & $72,00 \%$ \\
\hline & Secara cepat & 5 & $21.70 \%$ & 7 & $28,00 \%$ \\
\hline \multirow[t]{3}{*}{6} & Konsumsi air putih & & & & \\
\hline & $\mathrm{Ya}$ & 16 & $69,60 \%$ & 13 & $52,00 \%$ \\
\hline & Tidak & 7 & $30,40 \%$ & 12 & $48,00 \%$ \\
\hline \multirow[t]{3}{*}{7} & Pengunaan APD & & & & \\
\hline & $\mathrm{Ya}$ & 1 & $4,30 \%$ & 2 & $8,00 \%$ \\
\hline & Tidak & 22 & $95,70 \%$ & 23 & $92,00 \%$ \\
\hline \multirow[t]{3}{*}{8} & Perilaku merokok & & & & \\
\hline & $\mathrm{Ya}$ & 21 & $91,30 \%$ & 19 & $76,00 \%$ \\
\hline & Tidak & 2 & $8,70 \%$ & 6 & $24,00 \%$ \\
\hline \multirow[t]{3}{*}{9} & Konsumsi alkohol & & & & \\
\hline & Ya & 19 & $82,60 \%$ & 20 & $80,00 \%$ \\
\hline & Tidak & 4 & $14,40 \%$ & 5 & $20,00 \%$ \\
\hline
\end{tabular}


Masa kerja yang >10 lebih banyak pada kelompok kasus dan kelompok kontrol dengan presentase masing-masing 95,70\% untuk kelompok kasus dan 96,00\% untuk kelompok kontrol, dan menurut variabel kedalaman menyelam lebih banyak pada kelompok kasus dan kelompok kontrol yang kedalaman menyelamnya $>10$ meter dengan masing-masing presentase 73,90\% pada kelompok kasus dan 68,00\% pada kelompok kontrol. Berdasarkan distribusi frekuensi untuk masing-masing variabel penelitian untuk kelompok kasus dan kelompok kontrol lebih cenderung banyaknya responden pada variabel yang lama menyelamnya $>1$ jam, kecepatan naik ke permukaan yang dilakukan secara tidak cepat, perilaku K3 yang mengkonsumsi air putih, yang tidak menggunakan APD, yang merokok maupun mengkonsumsi alkohol.

\section{Analisis Bivariat}

Tabel 3. Hasil uji Chi-square

\begin{tabular}{|c|c|c|c|c|c|c|c|c|}
\hline \multirow{3}{*}{ Variabel } & \multicolumn{4}{|c|}{ Penyakit dekompresi } & \multirow{2}{*}{\multicolumn{2}{|c|}{ Total }} & \multirow{3}{*}{$\mathrm{p}$-value } & \multirow{3}{*}{$\begin{array}{c}\text { OR } \\
(95 \% \mathrm{CI})\end{array}$} \\
\hline & \multicolumn{2}{|c|}{ Kasus } & \multicolumn{2}{|c|}{ Kontrol } & & & & \\
\hline & $\mathrm{n}$ & $\%$ & $\mathrm{n}$ & $\%$ & $\mathrm{n}$ & $\%$ & & \\
\hline \multicolumn{9}{|l|}{ Masa kerja } \\
\hline$>10$ tahun & 22 & $95.70 \%$ & 24 & $96.00 \%$ & 46 & $95.80 \%$ & \multirow{2}{*}{0.121} & 4.600 \\
\hline$<10$ tahun & 1 & $4.30 \%$ & 1 & $4.00 \%$ & 2 & $4.20 \%$ & & $(0.577-36.668)$ \\
\hline \multicolumn{9}{|l|}{ Kedalaman menyelam } \\
\hline 10 meter & 6 & $26.10 \%$ & 8 & $32.00 \%$ & 14 & $95.80 \%$ & \multirow{2}{*}{0.003} & 0.137 \\
\hline$>10$ meter & 17 & $73.90 \%$ & 17 & $68.00 \%$ & 34 & $95.80 \%$ & & $(0.032-0.584)$ \\
\hline \multicolumn{9}{|l|}{ Lama menyelam } \\
\hline $1 \mathrm{jam}$ & 8 & $34.80 \%$ & 4 & $16.00 \%$ & 12 & $95.80 \%$ & \multirow{2}{*}{0.000} & 0.067 \\
\hline$>1 \mathrm{jam}$ & 15 & $65.20 \%$ & 21 & $84.00 \%$ & 36 & $95.80 \%$ & & $(0.013-0.348)$ \\
\hline \multicolumn{9}{|l|}{ Frekuensi menyelam } \\
\hline 1 kali / hari & 3 & $13.00 \%$ & 2 & $8.00 \%$ & 5 & $95.80 \%$ & \multirow{2}{*}{0.000} & 0.058 \\
\hline$>1 \mathrm{kali} /$ hari & 20 & $87.00 \%$ & 23 & $92.00 \%$ & 43 & $95.80 \%$ & & $(0.013-0.265)$ \\
\hline \multicolumn{9}{|c|}{ Kecepatan naik ke permukaan } \\
\hline Tidak cepat & 18 & $78.30 \%$ & 18 & $72.00 \%$ & 36 & $95.80 \%$ & \multirow{2}{*}{0.542} & 0.600 \\
\hline Cepat & 5 & $21.70 \%$ & 7 & $28.00 \%$ & 12 & $95.80 \%$ & & $(0.115-3.133)$ \\
\hline \multicolumn{9}{|c|}{ Perilaku K3 Konsumsi air putih } \\
\hline Ya & 16 & $69.60 \%$ & 13 & $52.00 \%$ & 29 & $95.80 \%$ & \multirow{2}{*}{0.690} & 0.763 \\
\hline Tidak & 7 & $30.40 \%$ & 12 & $48.00 \%$ & 19 & $95.80 \%$ & & $(0.201-2.892)$ \\
\hline \multicolumn{9}{|l|}{ Perilaku K3 (APD) } \\
\hline Ya & 1 & $4.30 \%$ & 2 & $8.00 \%$ & 3 & $95.80 \%$ & \multirow{2}{*}{0.000} & 0.048 \\
\hline Tidak & 22 & $95.70 \%$ & 23 & $92.00 \%$ & 45 & $95.80 \%$ & & $(0.009-0.245)$ \\
\hline \multicolumn{9}{|l|}{ Perilaku K3 (merokok) } \\
\hline Ya & 21 & $91.30 \%$ & 19 & $76.00 \%$ & 40 & $95.80 \%$ & \multirow{2}{*}{0.505} & 1.667 \\
\hline Tidak & 2 & $8.70 \%$ & 6 & $24.00 \%$ & 8 & $95.80 \%$ & & $(0.368-7.553)$ \\
\hline \multicolumn{9}{|l|}{ Perilaku K3 (alkohol) } \\
\hline Ya & 19 & $82.60 \%$ & 20 & $80.00 \%$ & 39 & $95.80 \%$ & \multirow{2}{*}{0.093} & 3.095 \\
\hline Tidak & 4 & $17.40 \%$ & 5 & $20.00 \%$ & 9 & $95.80 \%$ & & $(0.797-12.028)$ \\
\hline
\end{tabular}

Berdasarkan analisis chi square pada tabel 3, menunjukan bahwa masa kerja >10 tahun yang menderita penyakit dekompresi pada kelompok kasus dengan persentase 95,70\% dan pada kelompok kontrol dengan persentase $96,00 \%$ dengan nilai $p$-value 0,121 . Kedalaman menyelam $>10$ meter yang menderita penyakit dekompresi pada kelompok kasus, dengan persentase 73,90\% dan pada kelompok kontrol 68,00\% dengan nilai p-value 0,003 . Lama menyelam $>1$ jam yang menderita penyakit dekompresi pada kelompok kasus dengan persentase $65,20 \%$ dan pada kelompok kontrol dengan persentase 84,00\% dengan nilai p-value sebesar 0,000. Frekuensi menyelam yang > 1 kali/hari yang menderita penyakit dekompresi pada kelompok kasus dengan persentase $87,00 \%$ dan pada kelompok kontrol dengan persentase 92,00\% dengan nilai $p$-value sebasar 0,000 .

Kecepatan naik yang kepermukaan yang dilakukan secara tidak cepat dan menderita penyakit dekompresi pada kelompok kasus dengan persentase 78,30\% dan pada kelompok kontrol dengan persentase $72,00 \%$ dengan nilai p-value sebesar 0,542. Perilaku K3 konsumsi air putih dan yang menderita penyakit dekompresi pada kelompok kasus dengan persentase 69,60\% dan pada kelompok kasus dengan persentase $52,00 \%$ dan memiliki nilai $p$-value sebesar 0,690. Perilaku penggunaan APD dan yang tidak menggunaka APD dan menderita penyakit dekompresi pada kelompok kasus dengan persentase 95,70\% dan pada kelompok kasus dengan persentase $92,00 \%$ dengan nilai $p$-value sebesar 0,000 .

Perilaku K3 merokok dan menderita penyakit dekompresi pada kelompok kasus dengan persentase $91,30 \%$ dan pada kelompok kontrol dengan persentase 76,00\% dengan nilai p-value sebesar 0,505. Perilaku K3 konsmsi alcohol dan menderita penyakit dekompresi pada kelompok kasus dengan persentase 82,60\% dan pada kelompok kontrol dengan persentase $80,00 \%$ dengan nilai $p$-value sebesar 0,093.

\section{Analisis Multivariat}

Berdasarkan tabel 4, maka hubungan antar variabel masa kerja dengan nilai p-value 0,121 dan niai OR 4.600 kali mempunyai kemungkinan berpengaruh terhadap kejadian dekompresi untuk variabel masa kerja yang 
$<10$ tahun, dibandingkan dengan masa kerja yang >10 tahun. Kedalaman menyelam dengan nilai $p$-value 0,003, lama menyelam dengan nilai $p$-value 0,000 , frekuensi menyelam dengan nilai p-value 0,000 , perilaku $\mathrm{K} 3$ penggunaan APD dengan nilai $p$-value 0,000 dan perilaku K3 konsumsi alkohol dengan nilai $p$-value 0,093, jika dilihat dengan uji korelasi berganda maka terdapat adanya hubungan yang signifikan yang mempunyai hubungan dengan penyakit dekompresi.

Tabel 4. Hasil uji regresi

\begin{tabular}{|c|c|c|c|c|c|}
\hline No & Variabel & p-value & OR $(95 \% \mathrm{CI})$ & Korelasi & Signifikan $(\mathrm{Uji}$ F) \\
\hline \multirow{3}{*}{1} & Masa kerja & & & \multirow{3}{*}{0,610} & \multirow{18}{*}{0,003} \\
\hline & $>10$ tahun & \multirow{2}{*}{0.121} & 4.600 & & \\
\hline & $<10$ tahun & & $(0.577-36.668)$ & & \\
\hline \multirow{3}{*}{2} & Kedalaman menyelam & & & \multirow{3}{*}{0,610} & \\
\hline & 10 meter & \multirow{2}{*}{0.003} & 0.137 & & \\
\hline & $>10$ meter & & $(0.032-0.584)$ & & \\
\hline \multirow{3}{*}{3} & Lama menyelam & & & \multirow{3}{*}{0,610} & \\
\hline & $1 \mathrm{jam}$ & \multirow{2}{*}{0.000} & \multirow{2}{*}{$\begin{array}{c}0.067 \\
(0.013-0.348)\end{array}$} & & \\
\hline & $>1$ jam & & & & \\
\hline \multirow{3}{*}{4} & Frekuensi menyelam & & & \multirow{3}{*}{0,610} & \\
\hline & 1 kali / hari & \multirow{2}{*}{0.000} & 0.058 & & \\
\hline & $>1$ kali / hari & & $(0.013-0.265)$ & & \\
\hline \multirow{3}{*}{5} & Perilaku K3 APD & & & \multirow{3}{*}{0,610} & \\
\hline & Ya & \multirow{2}{*}{0.000} & \multirow{2}{*}{$\begin{array}{c}0.048 \\
(0.009-0.245)\end{array}$} & & \\
\hline & Tidak & & & & \\
\hline \multirow{3}{*}{6} & Perilaku K3 alkohol & & & \multirow{3}{*}{0,610} & \\
\hline & $\mathrm{Ya}$ & \multirow[b]{2}{*}{0.093} & \multirow{2}{*}{$\begin{array}{c}3.095 \\
(0.797-12.028)\end{array}$} & & \\
\hline & Tidak & & & & \\
\hline
\end{tabular}

Maka dapat disimpulkan bahwa terdapat hubungan yang signifikan antara masa kerja, kedalaman menyelam, lama menyelam, frekuensi menyelam, perilaku K3 penggunaan APD, dan perilaku K3 konsumsi alkohol dengan penyakit dekompresi secara keseluruhan.

\section{PEMBAHASAN}

Umur sangat berpengaruh terhadap aktifitas menyelam karena mempunyai hubungan dengan kesehatan penyelam. Dalam melakukan aktifitas menyelam tidak ada batasan umur yang menjadi penentuan jika seseorang ingin melakukan aktifitas menyelam. Namun rata-rata umur yang ideal yang disarankan untuk melakukan aktfitas menyelam yaitu 16-35 tahun. Umur yang lebih muda lebih memiliki risiko yang lebih besar terhadap kesehatan penyelam, begitu pula umur yang sudah menua. ${ }^{(9)}$

Pendidikan merupakan proses pembelajaran yang harus diikuti dan dipenuhi oleh setiap orang. Rata-rata pendidikan bagi pekerja nelayan dalam data penelitian yang diperoleh, dimulai dari tamatan SD sampai dengan tamatan SMA. Dalam melakukan aktifitas menyelam tidak mengharuskan seseorang harus mempunyai tamatan pendidikan yang tinggi. Namun para nelayan harus mempunyai pengetahuan terkait dengan risiko maupun bahaya dalam melakukan aktifitas menyelam. Memang bagi para nelayan pengalaman sangat penting, jika aktifitas menyelam yang dilakukan sudah mendapatkan pengalaman yang banyak dari aktifitas yang dilakukan kesehariannya. Namun pendidikan memang merupakan faktor terpenting untuk mengetahui seberapa bahaya yang dihadapi ketika aktifitaas menyelam dilakukan. Karena tingkat pengetahuan seseorang diperlukan untuk melihat risiko serta bahaya yang akan dialami dalam sebuah pekerjaan yang dilakukan

Masa kerja yang lama dapat mempengaruhi lamanya seseorang terpapar dengan faktor risiko pada tempat kerjanya. Karena semakin lama penyelam melakukan aktifitas menyelam maka semakin besar pula paparan atau faktor risiko yang didapatkan pada lingkunganya. Semakin lama seseorang terpapar dengan perbedaan tekanan maka risiko untuk menderita penyakit dekompresi semakin besar. Masa kerja yang lama bagi seorang penyelam juga yang dapat menyebabkan gangguan kesehatan, kelumpuhan bahkan kematian.

Namun berbeda dengan penelitian dengan penelitian yang dilakukan syamila yang memaparkan bahwa masa kerja tidak secara langsung mempunyai pengaruh terhadap kejadian dekompresi untuk nelayan penyelam tradisional. Karena, masa kerja selain menjadi penentuan lamanya seseorang terpapar dengan faktor risiko, namun masa kerja yang lama juga dapat memberikan pengalaman yang lebih kepada nelayan penyelam karena semakin lama seseorang bekerja maka semakin banyak pengalaman dan pengetahuan yang diperoleh sehingga seseorang yang bekerja lebih lama juga akan berhati-hati dan lebih memperhatikan prosedur penyelaman. ${ }^{(10)}$

Hasil penelitian menunjukan bahwa adanya hubungan yang signifikan antara kedalaman menyelam dengan kejadian penyakit dekompresi. Seorang yang melakukan penyelaman yang semakin dalam maka akan semakin besar tekanan atmosfir yang diterima, dengan bertambahnya kedalaman, kemungkinan terkena penyakit 
dekompresi semakin besar. Apabila seseorang masuk ke bawah permukaan air dan melakuikan penyelaman yang semakin dalam, maka tekanan yang diakan diterimanya semakin hari semakin besar. Hal tersebut disebabkan oleh karena berat jenis air lebih tinggi dari pada udara. Sehingga tekanan yang diterima akan disalurkan ke sebagian atau seluruh organ tubuh termasuk jaringan tubuh.

Hasil penelitian untuk variabel kedalaman menyelam >30 meter dengan besarnya risiko 1,890 kali lebih tinggi dibandingkan dengan yang menyelam $<30$ meter. Hasil penelitian ini sesuai dengan penelitian Penelitian yang dilakukan oleh Angkatan laut USA antara tahun 1968-1981, dimana seorang penyelam yang mencapai kedalaman tertentu maka tekanan yang didapatnya semakin besar tergantung kedalaman yang dicapaimya. Penelitian ini sejalan dengan penelitian yang mengungkapkan bahwa kedalaman menyelam merupakan faktor risiko terkena penyakit dekompresi. ${ }^{(11)(12)}$

Hasil penelitian menunjukan bahwa bahwa adanya hubungan yang signifikan antara lama menyelam dengan kejadian penyakit dekompresi. Lama waktu menyelam mempunyai pengaruh untuk penyerapan dan pelepasan gas nitrogen dalam jaringan cepat dan jaringan lambat. Pembebanan nitrogen yang tinggi akan menyebabkan terjadinya penyakit dekompresi. Semakin lama menyelam maka akan banyak nitrogen yang dierap oleh tubuh sehingga dapat mengakibatkan keluhan-keluhan seperti lemas pada saat melakukan aktifitas dalam air, merasakan pusing serta keram pada beberapa anggota tubuh.

Penelitian yang dilakuka oleh Alfred A. Bove dalam artikel "Decompression Sickness" dia menjelaskan bahwa ketika lama aktu yang dihabiskan hanya untuk melakukan penyelaman dalam suatu lingkungan yang mempunyai tekanan besar dan mempunyai potensi yang besar maka merupakan faktor dapat berisiko erhadap gangguan penyelama terutama pada dekompresi. Lama menyelam akan berpengaruh pada tekanan yang diterima oleh penyelam sesuai kedalaman yang dicapainya. Semakin lama melakukan penyelaman maka tekanan akan semakin besar dirasakan bagi penyelam.

Lama menyelam terbukti menjadi faktor yang berpengaruh terhadap kualitas hidup yang buruk bagi seorang penyelam tradisional penderita penyakit dekompresi, menurut penelitian Sri Rahayu, menunjukkan hasil yang bermakna secara statistik $(\mathrm{p}=0,021, \mathrm{OR}=9,860$, dan 95\% CI =1,410 - 68,943). Dengan demikian lama menyelam $\geq 2$ jam memiliki besar risiko 9,860 kali lebih besar untuk terjadi kualitas hidup yang buruk dibandingkan dengan lama menyelam $<2$ jam. Hal ini selaras dengan penelitian yang menunjukkan bahwa lama menyelam $\geq 2$ jam merupakan faktor risiko kejadian penyakit dekompresi dengan $\mathrm{OR}=61,680$, dimana peningkatan risiko terjadi penyakit dekompresi akan menurunkan kualitas hidup seorang penyelam. ${ }^{(13)}$

Hasil penelitian menunjukan bahwa tidak adanya hubungan yang signifikan antara perilaku K3 konsumsi air putih dengan kejadian penyakit dekompresi. Keseimbangan cairan tubuh merupakan keseimbangan jumlah cairan yang masuk maupun yang keluar dari dalam tubuh. Keseimbangan cairan didalam tubuh dipengaruhi oleh seberapa banyak yang dikonsumsi dan pengeluaran cairan dalam tubuh akibat aktifitas fisik yang berat. Ketidakseimbangan yang terjadi dalam tubuh dapat menyebabkan cairan di dalam tubuh berkurang, yang akan dapat menimbulkan kejadian dehidrasi. Dehidrasi merupakan gangguan cairan pada tubuh atau berkurangnya air dalam tubuh. Hal ini terjadi karena pengeluaran lebih banyak daripada pemasukan. Gangguan ini disertai dengan gangguan ketidakseimbangan cairan elektrolit yang ada dalam tubuh.

Menurut hasil penelitian yang dikatakan bahwa seseorang yang mengalami dehidrasi akan lebih cepat menunjukan risiko terjadinya kejadian dekompresi dan menunjukkan kecenderungan ke arah kematian yang lebih cepat denga nilai $\mathrm{p}$ menunnjukan kurang dari nilai alfa $(\mathrm{p}<0,1)$, yang artinya status dehidrasi secara signifikan dapat mempengaruhi kejadian untuk mengalami dekompresi pada penyelam, apabila tidak mengkonsumsi banyak air putih, ataupun persediaan air putih, pada saat aktifitas menyelam dilakukan. ${ }^{\text {(14) (15) }}$

Namun hal tersebut berbea dengan penelitian yang dilakukan dilapangan, hasil penelitian menunjukan bahwa responden ada yang mengkonsumsi air putih ketika melakukan aktifitas menyelam dan tidak mengkonsumsi air putih. Responden yang mengkonsumsi air putih mempunyai keluhan bahwa tidak bisa melakukan penyelaman yang lama, merasa berat pada bagiam tubuh dan merasakan kekenyangan pada bagian perut apabila mengkonsumsi air putih pada saat melakukan penyelaman. Namun ketika tidak mengkonsumsi air putih maka tubuh terasa lebih ringan untuk melakukan aktifitas menyelam, penyelaman yang juga dilakukan lebih lama namun tidak merasa kehausan.

Hasil penelitian menunjukan bahwa tidak adanya hubungan yang signifikan antara perilaku K3 merokok dengan kejadian penyakit dekompresi, hal ini dibuktikan dengan hasil uji statistik diperoleh nilai $p$-value yang lebih besar yaitu 0.505 (> 0.050). Namun didapatkan angka odd ratio untuk perilaku K3 (merokok) sebesar 1.667, untuk perilaku K3 (merokok), dan mempunyai kecederungan untuk berisiko penyakit dekompresi.

Merokok juga sebaiknya tidak dilakukan sebelum dan sesudah menyelam. Jika seseorang termasuk dalam perokok aktif, maka diharuskan untuk dihindari mengkonsumsi rokok selama beberapa jam sebelum dan sesudah melakukan aktifitas menyelam. Karena secara signifikan dapat mengurangi efisiensi sistem sirkulasi dan pernapasan. Merokok secara teoritis meningkatkan risiko cedera pada paru-paru dengan menyebabkan udara terperangkap di dalam paru-paru bahkan ketika bernapas dengan normal. Merokok tak menimbulkan resiko secara langsung jika kita mengkonsumsinya. Namun disarankan hal ini pun tak dilakukan sebelum dan sesudah menyelam. ${ }^{(11)}$ 
Hasil penelitian menunjukan tidak adanya hubungan yang signifikan antara perilaku K3 konsumsi alkohol dengan kejadian penyakit dekompresi, hal ini dibuktikan dengan hasil uji statistik diperoleh nilai $p$ value yang lebih besar yaitu 0.093 (> 0.050). Namun didapatkan angka odd ratio untuk perilaku K3 (alkohol) sebesar 3.095, dan mempunyai kecederungan untuk berisiko penyakit dekompresi. Mengkonsumsi alkohol dalam waktu yang lama dengan kadar yang tinggi dapat menyebabkan sejumlah gangguan pada neurologis seseorang. Seseorang yang ketika mengkonsumsi dengan banyak dan dalam jangka waktu yang lama, maka akan mengalami kelemahan pada beberapa fungsi intelektual seseorang, emosi yang bersifat labil, penurunan persepsi dan bias sampai pada tingkat amnesia. Mengonsumsi minuman beralkohol berbahaya bagi sorang yang melakukan penyelaman. Padahal menyelam membutuhkan konsentrasi dan kepekaan menilai sesuatu dalam kondisi darurat demi keselamatan penyelaman ketika munculnya risiko menyelam. ${ }^{(16)}$

\section{KESIMPULAN}

Adanya hubungan yang signifikan antara kedalaman menyelam, lama menyelam, frekuensi menyelam, dan perilaku K3 penggunaan APD dengan kejadian penyakit dekompresi pada nelayan penyelam tradisional di Ambon. Dan tidak adanya hubungan yang signifikan antara masa kerja, kecepatan naik ke permukaan, perilaku K3 konsumsi air putih, perilaku K3 merokok dan perilaku K3 konsumsi alkohol dengan kejadian penyakit dekompresi pada nelayan penyelam tradisional di Ambon.

\section{DAFTAR PUSTAKA}

1. Gunawan, Nani, Fauziah R, Zulham, Djamaludin, Pramono ${ }^{1}$ H, et al. New Homes on Misty Mountains: Javan Hawk-eagle Nisaetus bartelsi and Changeable Hawk-eagle Nisaetus cirrhatus Nesting in Gunung Halimun Salak National Park, West Java, Indonesia. 2017;3(1):1-5.

2. Andayani sri SI. Peranan Program Budaya Keselamatan Dalam Mendukung Kesehatan Dan Keselamatan Kerja. 2018.

3. Made N, Linggayani A, Ramadhian MR, Mikrobiologi B, Kedokteran F, Lampung U. Penyakit Caisson pada Penyelam.

4. Arsin AA, Naiem F. FAKTOR RISIKO KEJADIAN DECOMPRESSION SICKNESS PADA PULAU SAPONDA Risk Factors of Decompression Sicknessin Traditional Divers of a Fishing Community in Saponda Island. 2016;12(2):63-9.

5. Hall J. The risks of scuba diving: a focus on Decompression Illness. Hawaii J Med Public Health [Internet]. 2014;73(11 Suppl 2):13-6.

6. Dharmawirawan DA, Moedjo R. Identifikasi Bahaya Keselamatan dan Kesehatan Kerja pada Penangkapan Ikan Nelayan Muroami. J Kesehat Masy Nas. 2012;6(4):185-92.

7. Achmad I, Soulisa J, Latuconsina L. Hubungan Pengunaan Alat Penyelam Tradisional Dengan Kejadian Barotrauma. Glob Heal Sci. 2016;1(1):13-23.

8. Sugiyono. Metodologi Penelitian. Sugiyono, editor. Bandung: AFABETA; 2015.

9. Aziz AA. Studi Kasus Sindroma Caisson Pada Penyelam Kompressor Di Pulau Barrang Lompo Makassar Tahun 2010. 2010;77.

10. Abdullah AZ, Palutturi S, Wijaya DR. Faktor Risiko Masa Kerja Dan Waktu Istirahat Terhadap Kejadian Penyakit Dekompresi Pada Nelayan Penyelam Di Pulau Barrang Lompo. Jkmm [Internet]. 2018;2(1):194203.

11. Widyastuti SR, Hadisaputro S, Munasik M. Berbagai Faktor yang Berpengaruh Terhadap Kualitas Hidup Penyelam Tradisional Penderita Penyakit Dekompresi. J Epidemiol Kesehat Komunitas. 2019;4(1):45.

12. Kartono SA (UGM). Bahaya Tekanan Tinggi di Bawah Permukaan Air. 2011;202-11.

13. Irkhami FL. Faktor Yang Berhubungan Dengan Stres Kerja Pada Penyelam Di Pt. X. Indones J Occup Saf Heal. 2015;4(1):54.

14. Puspita M, Kesehatan S $\square$, Kerja K, Ilmu J, Masyarakat K, Keolahragaan I, et al. 08 Higeia 1 (2) (2017) Higeia Journal of Public Health Research and Development Iklim Kerja Panas Dan Konsumsi Air Minum Saat Kerja Terhadap Dehidrasi. 2017;1(2):108-18.

15. Sari NA, Nindya TS. Hubungan Asupan Cairan, Status Gizi dengan Status Hidrasi pada Pekerja di Bengkel Divisi General. Media Gizi Indones. 2017;12(1):47-53.

16. Duke HI, Hadisaputro S, Chasani S, Anies A, Munasik M. Beberapa Faktor yang Berpengaruh terhadap Kejadian Penyakit Dekompresi pada Penyelam Tradisional (Studi Kasus di Karimunjawa). J Epidemiol Kesehat Komunitas [Internet]. 2016;1(1):9-14. 